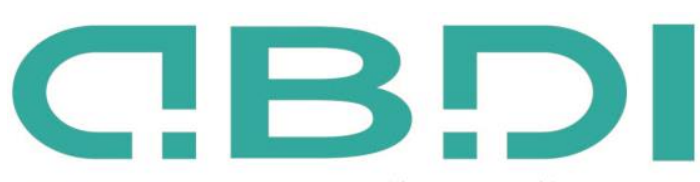

ABDI: JURNAL PENGABDIAN DAN PEMBERDAYAAN MASYARAKAT

\title{
Assesoris Kreatif dari Sampah Bagi Anak Asuh di Panti Asuhan Aisyiyah Koto Tangah Muaro Penjalinan Kota Padang
}

\author{
Nora Susilawati ${ }^{1}$, Hendra Naldi ${ }^{2}$ \\ ${ }^{1}$ Jurusan Sosiologi Universitas Negeri Padang \\ ${ }^{2}$ Jurusan Sejarah Universitas Negeri Padang \\ Email: susilawatinora@gmail.com
}

\begin{abstract}
Abstrak
Sampah adalah sesuatu yang biasanya dipandang oleh orang sebagai barang yang kotor, tidak berguna, dan harus dibuang. Ini adalah suatu persepsi yang tidak tepat, karena sampah jika diolah dengan baik dan kreatif dapat menjadi barang yang berguna dan bernilai ekonomi. Jadi, sampah tidak selamanya harus dibuang, karena dapat diubah menjadi beraneka produk yang berharga. Sampah-sampah seperti sampah plastik, botol-botol bekas dan kain perca dapat diubah menjadi tas, bros, kotak pensil, payung, bunga dan lain sebagainya. Tulisan ini akan menguraikan bagaimana pembuatan assesoris kreatif yang dibuat oleh para anak asuh di Panti Asuhan Aisyiyah Koto Tangah Muaro Penjalinan Kota Padang. Assesoris yang dibuat adalah bros, tas kecil, dan kotak pensil yang terbuat dari kain-kain perca yang tidak terpakai. Sebelum pembuatan assesoris terlebih dulu diberikan pengetahuan tentang dampak sampah terhadap manusia dan lingkungan dan bagaimana mengolah sampah tersebut menjadi sesuatu yang bermanfaat dan bernilai ekonomi.

Kata Kunci: Assesoris, Kreatif, Sampah, Anak asuh

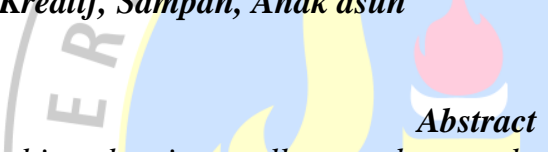

Garbage is something that is usually seen by people as dirty, useless, and must be discarded. This is a perception that is not right, because waste if processed properly and creatively can be useful and economic value. So, garbage does not always have to be discarded, because it can be converted into various valuable products. Rubbish such as plastic waste, used bottles and patchwork can be turned into bags, brooches, pencil boxes, umbrellas, flowers and so on. This paper will describe how to make creative accessories made by foster children at the Aisyiyah orphanage Koto Tangah Muaro Penjalinan Padang. Accessories made are brooches, small bags, and pencil boxes made of unused patchwork. Before making an accessory first, knowledge of the impact of waste on humans and the evironment is given and how to process the waste into something useful and economic value.
\end{abstract}

Key Word: Acceessories, Creative, Garbage, Foster child

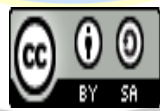

Received: 18 Maret 2019 


\section{Pendahuluan}

Kreatifitas anak dapat dikembangkan melalui lembaga formal dan non formal. Salah satu lembaga non formal tersebut adalah melalui panti asuhan. Umumnya panti asuhanmenampung dan membina anakanak yatim piatu ataupun anak-anak terlantar. Karena menampung dan membina anak-anak yatim dan anak-anak terlantar, maka panti asuhan juga dapat menjadi lembaga usaha kesejahteraan sosial. Cara yang dilakukan adalah dengan membekali mereka keterampilan berupa kerajinan tangan. Keterampilan tersebut dapat menjadikan mereka lebih kreatif dan produktif.

Salah satu bentuk keterampilan yang diberikan adalah membuat kerajinan tangan yang terbuat dari barang-barang bekas, seperti botol-botol bekas, plastik-plastik bekas, kertas-kertas, kain perca dan lain-lain. Saat ini pembuatan kerajinan tangan dari barang-barang bekas atau sampah semakin berkembang di lingkungan masyarakat dan pemerintah juga telah menggagas bahwa kerajinan tangan dari sampah dapat mengurangi volume sampah di Kota Padang. Kreatifitas masyarakat mengolah sampah menjadi barang berguna dalam rangka pengelolaan sampah berbasis pemberdayaan masyarakat.Hal ini sesuai dengan Peraturan Daerah Nomor 21 tahun 2012tentang pengelolaan sampah. Masyarakat tidak lagi menganggap bahwa sampah tidak dianggap musuh, tidak berguna dan harus dibuang tetapi barang yang berguna dan bernilai ekonomi.

Kemunculan bank sampah di Kota Padang juga telah merubah persepsi masyarakat tentang sampah. Sebelumnya masyarakat menganggap bahwa sampah dianggap kotor, dan tidak terpakailagi berubah menjadi barang barang yang dianggap penting, cantik dan memberi keuntungan secara ekonomi. Sampah yang dulunya dianggap musuh justru dikumpulkan. Sampah plastik, botol-botol, dan kertaskertas tidak akan terurai sehingga dapat merusak lingkungan hidup. Masyarakat juga menjadi terbiasa mengumpulkan sampah yang mereka temukan di jalan, di lingkungan tempat tinggal dan di rumah sendiri lalu mereka tabung di bank sampah (Syafrini dan Nora, 2012). Begitu juga penelitian yang juga pernah penulis lakukan di kawasan pantai purus Padang, masyarakat telah memiliki kesadaran tentang kebersihan lingkungan, apalagi kawasan pantai telah menjadi kawasan wisata, mereka harus menjaga kebersihan dan keindahan lingkungan. Masyarakat mengumpulkan sampah yang ada di sekitar kawasan wisata, lalu dibuat beberapa assesoris cantik dan unik. Kemudian, assesoris tersebutmereka jual. Sampah akhirnya dapat memberikan sesuatu yang bermanfaat bagi kehidupan ekonomi masyarakat di sekitar kawasan wisata pantai Purus Kota Padang (Syafrini \& Nora, 2015).

Penulis juga pernah melakukan kegiatan pelatihan di Panti Asuhan Aisyiyah lain di Jalan Ampang Kota Padang pada tahun 2017 hasilnya adalah anak asuh panti asuhan hingga saat ini tetap berkreasi membuat bros, kalung, dan gelang untuk di jual di acara acara arisan ibu-ibu di sekitar kawasan panti, di sekolah-sekolah dan di toko-toko assesoris yang ada di Kota Padang. Ini membuktikan bahwa usaha mereka berjalan dengan baik dan mereka dapat melanjutkan pendidikannya hingga ke perguruan tinggi, bahkan ada satu orang yang kuliah di UNP. Salah satu lokasi yang juga potensial untuk diberikan pelatihan pembuatan kerajinan tangan yang bernilai jual adalah Panti Asuhan Aisyiyah Koto Tangah yang terletak di Jalan Adinegoro No 37 A Muaro Penjalinan Kota Padang. Panti asuhan ini menampung anak anak perempuanyang terdiri dari anak-anak yatim, piatu, yatim piatu dan miskinyang tinggal di dalam dan luar panti. Lebih jelasnya jumlah anak asuh panti asuhan ini dapat dilihat pada tabel di bawah ini.

Tabel 1. Jumlah Anak Asuh di Panti Asuhan Aisyiyah Koto Tangah

\begin{tabular}{clcc}
\hline No & Kategori Anak Asuh & Dalam Panti & Luar Panti \\
\hline 1 & Yatim & 12 & 15 \\
\hline 2 & Piatu & 6 & 1 \\
\hline 3 & Yatim Piatu & 2 & 2 \\
\hline 4 & Miskin & 14 & 27 \\
\hline & Jumlah & 34 & 45 \\
\hline & Sumber: Data Panti Asuhan Aisyiyah Koto Tangah tahun 2016
\end{tabular}

ABDI: Jurnal Pengabdian dan Pemberdayaan Masyarakat Vol. 1 No. 1
E-ISSN: 2684-8570| ABDI 2019
Copyright` 2019, By Author 
Rata-rata anak asuh masih bersekolah di tingkat SD, SMP, SMA dan perguruan tinggi. Kendala utama yang dihadapi oleh pengelola panti dalam melaksanakan operasional kegiatan sehari-hari dan biaya sekolah adalah adanya keterbatasan dana. Semua operasional ditanggung oleh yayasan dan para donator. Anak asuh membutuhkan biaya untuk keperluan sekolah dan kelanjutan pendidikannya.

Berdasarkan hasil wawancara dengan anak asuh panti, mereka berkeinginan untuk dapat membuat sesuatu yang bisa menghasilkan uang. Mereka ingin membuat sendiri kebutuhan peralatan sekolah seperti kotak pensil, tas sekolah, buku agenda, dan berbagai assesoris cantik dan unik. Namun masalahnya mereka tidak mengetahui cara membuatnya. Ibu Rafidah sebagai ketua pengelola panti juga sangat antusias jika anak-anak asuhnya diberi pengetahuan dan keterampilan yang bermanfaat.

Kawasan Panti Asuhan Aisyiyah Muaro Penjalinan di Jalan Adinegoro ini berada di pinggir jalan dan banyak terdapat warung makanan dan minuman, toko-toko, tukang jahit pakaian, dan usaha lain yang banyak memproduksi sampah setiap hari seperti botol-botol bekas, kertas-kertas, sampah plastik makanan ringan, kain-kain perca, dan lain-lain. Sampah-sampah ini dapat dijadikan untuk asssesoris dan kebutuhan peralatan sekolah yang diminati oleh pelajar, mahasiswa, ibu-ibu rumah tangga. Barang-barang bekas atau sampah dapat dibuat seperti tas, kotak pensil, buku agenda, bros, hiasan dinding, tempat sampah, celengan, tempat tisu, jepitan rambut, kalung, dompet, pas bunga dan lain lain. Berdasarkan kondisi itulah perlu memberikan kontribusi kepada pengelola dan anak asuh Panti Asuhan Aisyiyah yang dikategorikan masih usia produktif dan memiliki keinginan yang kuat untuk membuat sampah menjadi barang-barang yang berguna dan bernilai ekonomi.

Secara umum ditemukan permasalahan yaitu masyarakat termasuk anak asuh dan pengelola panti masih menganggap bahwa sampah dianggap sesuatu yang kumuh/kotor dan harus dibuang. Secara khusus permasalahan yang ditemukan yaitu: 1) kurangnya pengetahuan anak asuh panti dalam mengelola sampah menjadi usaha kreatif yang berguna dan bernilai ekonomi; dan 2) kurangnya keterampilan anak asuh dalam membuat assesoris kreatifyang sesuai dengan trend masyarakat saat ini, Padahal sampah seperti botol-botol bekas, plastik-plastik makanan dan minuman bekas, kain perca dan kertas-kertas bila dikelola secara tepat menjadi barang-barang berguna dan bernilai ekonomi Dengan demikian yang menjadi pertanyaannya adalah bagaimana sampah dapat dibuat menjadi assesoris kreatif oleh anak asuh ?

\section{Kepribadian Kreatif dalam Mengelola Sampah}

Dilihat dari sudut teori kepribadian kreatif Hagen menjelaskan bahwa perkembangan ekonomi masyarakat dapat ditingkatkan melalui peningkatan pendapatan secara terus menerus. Proses perkembangan ekonomi tersebut berkaitan dengan individu-individu kreatif yang menciptakan hubungan sosial sepanjang waktu. Perubahan masyarakat tidak akan terjadi tanpa adanya perubahan dalam kepribadian individu. Perubahan kepribadian dilihat dari segi kebutuhan, nilai-nilai, tingkat intelegensi dan energi. Hal inilah yang menyebabkan individu dapat bertindak sesuai dengan situasi. Kebutuhan penting dalam bertindak adalah kebutuhan berprestasi (Lauer, 2011)

Hagen membedakan antara kepribadian inovatif dan kepribadian otoriter. Kepribadian inovatif mempunyai tatanan logis dalam memahami lingkungan sosialnya dan selanjutnya lingkungan sosial menilai dirinya. Penilaian tersebut berdasarkan pada prestasi sehingga menyebabkan individu ingin melakukan prestasi tersebut. Individu akan memelihara dan meyakini nilai-nilai dirinya sendiri dan terdorong untuk berprestasi. Perilaku kreatif adalah termasuk dalam kepribadian inovatif.

Adapun ciri-ciri kepribadian kreatif adalah:

a. Kebutuhan yang sangat besar terhadap otonomi dan keteraturan.

b. Pemahaman sendiri yang meningkatkan tegasnya terhadap orang lain.

c. Kebutuhan yang besar untuk memelihara dan memikirkan kesejahteraan orang lain dan kesejahteraan dirinya sendiri. 
Kepribadian otoriter tidak yakin bahwa ia dinilai oleh lingkungan sosialnya. Kekuasaan adalah sebagai fungsi dari posisi yang diduduki dari pada fungsi mencapai prestasi yang diraih seseorang. Kepribadian otoriter lebih kepada menundukkan, kurangnya memelihara dan otonomi untuk berprestasi serta adanya ketidakseimbangan antara berbuat untuk kesejahteraan orang lain dan kesejahteraan dirinya.

Pemanfaatan sampah menjadi barang-barang berguna dan bernilai ekonomi akan terwujud bila adanya kepribadian kreatif anak asuh panti. Diharapkan mereka nantinya dapat memperoleh pendapatan dari hasil kreatifitas mereka sendiri sehingga dapat meningkatkan kesejahteraan untuk dirinya dan orang lain.

\section{Motivasi Berprestasi dalam Menciptakan Wirausaha Kreatif}

David Mc. Clelland (Martono, 2011) menjelaskan bahwa masyarakat yang tinggi tingkat kebutuhan berprestasinya menghasilkan wiraswastawan yang lebih bersemangat dan mempercepat perkembangan ekonomi. Kebutuhan berprestasi merupakan kebutuhan dasar manusia dan hasil dari pengalaman sejak masa kanak-kanak. Cara-cara mengasuh atau memelihara anak akan membantu atau dapat merintangi perkembangan kebutuhan anak dalam berprestasi.

Motivasi untuk berprestasi berasal dari nilai-nilai, keyakinan dan ideologi yang dianut orang. Kebutuhan berprestasi diperoleh oleh anak pada usia 8 atau 10 tahun. Pengalaman penting dalam menciptakan kebutuhan berprestasi anak adalah melalui pelatihan kejuruan sejak dini dan kualitas interaksi antara orang tua dengan anak.

Berdasarkan dua pemikiran ahli tersebut yaitu Hagen dan Mc. Clelland menegaskan pentingnya peran individu dalam proses perubahan. Secara khusus peran individu yang kreatif dan memiliki kebutuhan untuk berprestasi yang tinggi dalam mendorong perkembangan ekonomi.

Semangat untuk berprestasi yang tinggi dari anak asuh panti akan melahirkan wirausaha kreatif. Umumnya anak asuh masih berada pada usia anak anak dan remaja. Usia ini merupakan usia yang masih produktif dan dibutuhkan pemberian semangat atau motivasi untuk berprestasi menciptakan barangbarang bergunadan bernilai ekonomi. Diharapkan mereka dapat memanfaatkan waktu luangnya untuk hal yang bermanfaat dan menguntungkan secara ekonomi yaitu dengan berkreasi membuat assesoris yang dibutuhkan dan menjadi trend masyarakat saat ini.

\section{Pemberdayaan Masyarakat dalam Sebagai Strategi Perubahan}

Pemberdayaan (empowerment) berasal dari kata "power" (kekuasaan atau keberdayaan). Kekuasaan juga sering dikaitkan dengan kemampuan individu untuk membuat orang lain melakukan apa yang diinginkannya, terlepas dari minat dan keinginan sendiri. Pemberdayaan memiliki pengertian dalam konteks budaya dan politik. Maknanya adalah mencakup kekuatan sendiri, kemandirian, pilihan sendiri, kedaulatan hidup sesuai dengan nilai-nilai yang dianut seseorang atau masyarakat, kapasitas untuk memperjuangkan hak, kemerdekaan, pembuatan keputusan sendiri, menjadi bebas, kebangkitan dan kapabilitas (Martono, 2011).

Konsep pemberdayaan menurut Ife dalam Martono (2011) adalah proses menyiapkan masyarakat dengan berbagai sumberdaya, kesempatan, pengetahuan, dan keahlian untuk meningkatkan kapasitas diri masyarakat dalam menentukan masa depan mereka, serta berpartisipasi dan mempengaruhi kehidupan dalam komunitas masyarakat itu sendiri. Untuk itu, dalam proses pemberdayaan sangat dibutuhkan partisipasi masyarakat. Pembangunan yang melihat partisipasi masyarakat disebut oleh Korten dan Syahrir (1996) sebagai pembangunan yang berdimensi kerakyatan atau yang berpusat pada rakyat.

Pemberdayaan dapat diterapkan pada tingkat individu maupun kelompok terkait dengan ekonomi, sosial dan politik. Pemberdayaan menunjuk pada kemampuan seseorang atau kelompok yang rentan dan lemah sehingga mewakili kemampuan dalam beberapa hal yaitu (Suharto, 2005):

1. Memenuhi kebutuhan dasar sehingga memiliki kebebasan pendapat, bebas dari kelaparan, bebas dari kebodohan atau kesakitan.

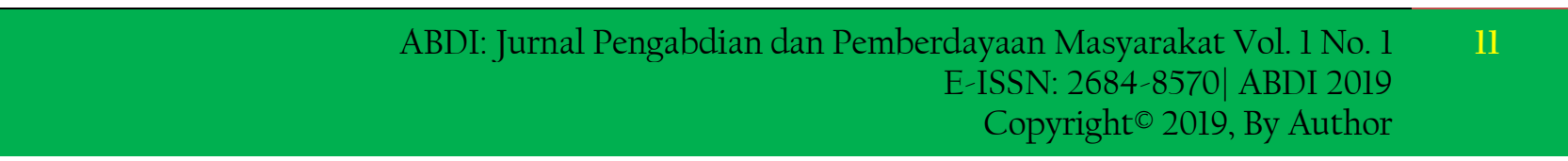


2. Menjangkau sumber-sumber produktif yang memungkinkan mereka dapat meningkatkan pendapatannya serta memperoleh barang-barang dan jasa yang diperlukan.

3. Berpartisipasi dalam proses pembangunan dan keputusan-keputusan yang mempengaruhi mereka.Dalam beberapa situasi strategi pemberdayaan dapat saja dilakukan secara individual tetapi tetap berkaitan dengan kolektifitas.

Model pemberdayaan masyarakat dapat melalui tiga tingkat yaitu mikro, meso dan makro. Pada tingkat mikro pemberdayaan dilakukan terhadap individu seperti stress management, crisis intervention dan bimbingan konseling. Pada tingkat meso pemberdayaan dilakukan terhadap kelompok sebagai media intervensi, seperti pendidikan dan pelatihan, dinamika kelompok, untuk meningkatkan kesadaran, pengetahuan, keterampilan dan sikap-sikap klien agar memiliki kemampuan memecahkan permasalahan yang dihadapi. Pada tingkat makro, pemberdayaan diarahkan pada sistem lingkungan yang lebih luas untuk merumuskan kebijakan, perencanaan sosial, kampanye, aksi sosial, pengorganisasian konflik dan manajemen konflik

Pada program ini, model pemberdayaan yang dilakukan adalah pada tingkat meso, yaitu melalui pelatihan pembuatan assesoris/kerajinan tangan dari sampah menjadi barang-barang berguna dan bernilai ekonomi. Menurut Undang-Undang Nomor 18 tahun 2008, sampah adalah kegiatan sehari-hari manusia dan/atau dari proses alam yang berbentuk padat, harus dikelola dengan sistem ramah lingkungan untuk melestarikan lingkungan hidup dan menjadikan sampah menjadi bernilai guna. Untuk itu masyarakat harus dilibatkan dalam pengelolaan sampah.

Pelatihan yang dilakukan terhadap anak asuh panti bertujuan untuk meningkatkan kesadaran bahwa sampah juga bermanfaat ekonomi bukan sesuatu yang kumuh dan tidak berguna sehingga dibuang semuanya. Pengetahuan dan keterampilan yang diberikan kepada anak asuh panti, karena mereka mempunyai keinginan yang kuat untuk membuat assesoris namun kurang memiliki keterampilan untuk membuatnya.

Berangkat dari permasalahan dan teori di atas, maka solusi konkrit yang ditawarkan untuk mengatasi permasalahan anak asuh panti di antaranya adalah :

1. Memberikan pengetahuan dan urgensi pengelolaan sampah untuk kelestarian lingkungan dan peningkatan kesejahteraan secara ekonomi

2. Memberikan motivasi untuk menjadi wirausaha kreatif dalam memanfaatkan sampah sebagi sumber usaha

3. Memberikan pelatihan pembuatan assesoris yang unik dan bernilai ekonomi seperti tas, bros, dan kota pensil yang diminati saat ini.

4. Melakukan advokasi dalam kegiatan wirausaha kreatif anak asuh panti dan memasarkan hasil karya mereka di pasar lokal dan media sosial.

Setelah kegiatan pelatihan dilaksanakan, maka diharapkan terjadinya peningkatan pengetahuan dan ketarampilan anak asuh dalam mengelolah sampah menjadi assesoris yang kreatif. Selain itu, juga dapat menumbuhkan jiwa kemandirian anak asuh secara ekonomi agar mereka dapat memenuhi kebutuhannya di masa depan melalui wirausaha kreatif secara berkelanjutan.

\section{Metode Pelaksanaan}

\section{Khalayak Sasaran dan Lokasi}

Sasaran kegiatan ini adalah anak asuh Panti Asuhan Aisyiyah Koto Tangah yang terletak di Jalan Adinegoro Muaro Penjalinan Kota Padang. Panti asuhan ini diperuntukkan bagi anak perempuan yang merupakan anak yatim, piatu, yatim piatu dan fakir miskin yang kekurangan dana. Kondisi ekonomi yang kurang namun memiliki keinginan yang kuat menjadi alasan untuk dilakukannya pelatihan untukmeningkatkan kemandirian, kreatifitas, dan jiwa wirausaha. Peserta adalah anak asuh panti. Anak asuh panti masih sekolah di tingkat SD, SMP dan SMA bahkan perguruan tinggi. Merekaadalah anak 
asuh yang tinggal di panti dan di sekitar panti namun berada dalam binaan panti. Peserta terdiri dari orang, terdiri dari 30 orang yang tinggaldi panti dan 5 orang yang tinggal di luar panti. Pelatihan dilakukan adalah pada hari Sabtu dan Minggu tanggal 1,2,8, 9, 15 dan 16 September 2018.

\section{Pendekatan yang Digunakan}

Pendekatan yang dipakai adalahpendekatan social learning theory. Para peserta dalam program pelatihan diharapkan mampu mendapatkan dan mengaplikasikan kompetensi khusus yang didapat selama program pelatihan. Motivasi untuk belajar mengenai hal-hal baru menjadi dasar suksesnya sebuah pelatihan karena menciptakan proses pembelajaran yang kondusif, yang pada gilirannya nanti setelah pelatihan diharapkan peserta dapat menerapkan pengetahuan, keterampilan dan sikap yang mereka peroleh dalam pelatihan.

\section{Hasil dan Pembahasan}

Kegiatan dilaksanakan dalam 4 tahap yaitu tahap penyampaian materi dari narasumber, tahap pelatihan pemilahan sampah, tahap praktik pembuatan assesoris dan tahap advokasi wirausaha kreatif.

Pertama, penyampaian materi dari nara sumber berkaitan dengan pemanfaatan sampah yang bisa dijadikan sebagai salah satu sumber pendapatan. Penyampaian materi dilakukan tanggal 1 September 2018 yang dimulai pada pukul 09.00 WIB hingga 12.30 WIB.Pada tahap ini nara sumber terlebih dulu memberikan penjelasan tentang adanya sampah yang masih dimanfaatkan dan bagaimana bahayanya sampah jika salah memahaminya. Materi disampaikan dengan menggunakan power point dan video animasi Ozzy Ozzon yang memperlihatkan bagaimana dampak sampah yang muncul karena pengelolaan sampah yang salah. Dampak yang ditimbulkan dengan adanya sampah adalah adanya penyakit, mengancam keselamatan manusia dan bumi. Sampah yang basah yang mudah terurai jika tercampur dengan sampah plastik, maka akan sulit terurai. Plastik membutuhkan waktu ratusan tahun bisa terurai. Kota Padang yang memiliki TPA untuk pembuangan sampah akan semakin tidak tertampung lagi di Air Dingin Kota Padang. Untuk itu jika sampah yang tidak bisa terurai dapat didaur ulang dan dimanfaatkan akan mengurangi jumlah sampah yang semakin banyak.

Penyampaian materi pada tahap ini bertujuan menambah wawasan peserta tentang pelestarian lingkungan dan diharapkan mengubah persepsi peserta tentang sampah yang bisa bernilai ekonomi bukan sebagai benda yang negatif dan harus dibuang.

Kedua, Pelatihan pemilahan pengolahan sampah menjadi assesoris berguna dan bernilai ekonomi. Pada tahap ini peserta diberikan cara memilah sampah dan mengolah sampah. Nara sumber mengajak peserta bahwa sampah adalah bisa mendatangkan sejumlah keuntungan. Menurut Undang-Undang No.18 tahun 2008 sampah harus dikelola dengan sistem yang ramah lingkungan untuk melestarian lingkungan hidup dan menjadikan sampah memiliki nilai guna bagi masyarakat. Pengelolaan sampah rumah tangga yang disarankan adalah dengan; (1) Membatasi jumlah sampah rumah tangga, sepertiplastik belanja dan diminta menggunakan kantong atau keranjang bila belanja. Dengan cara ini, penggunaan plastik lebih hemat pengeluaran keluarga juga hemat. Jika masing-masing keluarga melakukan cara ini produksi sampah bisa diminimalisasi. (2) Memilah sampah sebelum masuk ke tempat sampah, yaitu sampah basah dan sampah kering. Sampah basah bisa diolah menjadi pupuk kompos, sampah kertas dan botol bisa dijual. Sementara sampah plastik seperti plastik mie instant, plastik deterjen, plastik makanan dan minumanbisa didaur ulang menjadi assesoris cantik dan bernilai ekonomi.

Ketiga, Praktek pembuatan assesoris dari sampah. Tahap ini dilakukan praktek pembuatan assesoris yang diberikan oleh Widya Oktavia dan Fenta Retmawati sebagai instruktur yang memiliki skill dalam pembuatan assesoris seperti tas, bros dan kotak pensil 
Adapun langkah kerja yang dilakukan adalah sebagai berikut:

a. Pembagian Kelompok Kerja

Pada tahap ini instruktur membagi peserta menjadi 5 kelompok. Masing-masing kelompok mendapatkan alat dan bahan seperti gunting, pistol lem tembak, kain perca, mutiara, manik-manik, tali kalung, plastik dan bahan lainnya.

b. Pelatihan Pengelolaan Kain Perca Menjadi Assesoris

Pada tahap ini instruktur memberikan contoh dan langkah-langkah pengolahan kain perca menjadi assesoris seperti bros, tas, dan kotak pensil. Pelatihan dilakukan dengan menggunakan dua metode yaitu melalui video dan praktek langsung dari proses awal sampai selesai.

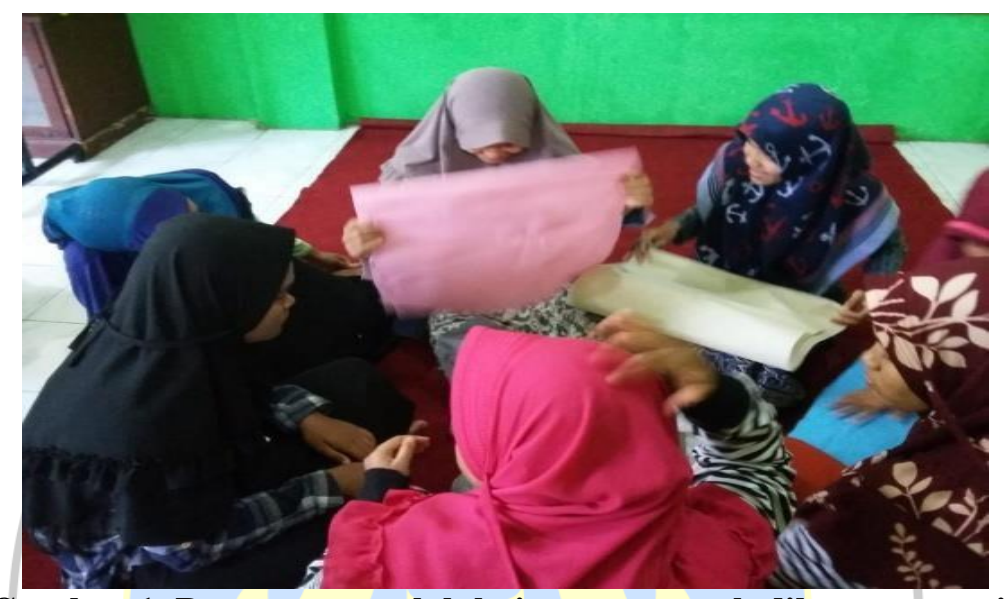

c. Praktek Pembuatan Assesoris

\section{Gambar 1. Peserta mengolah kain perca untuk dibuat assesoris}

Pada tahap ini peserta melakukan praktek langsung membuat tas, kotak pensil dan bros yang dilakukan setiap orang dalam kelompok. Praktek dibimbing langsung oleh 2 orang instruktur dan didampingi oleh 2 orang mahasiswa yang dilibatkan. Masing-masing peserta berhasil membuat assesoris tas, bros dan kotak pensil. Untuk memotivasi peserta dalam pelatihan dan berkarya maka tim telah menyediakan reward/ hadiah untuk kelompok sehingga peserta semangat dalam mengikutipelatihan. Pada saat praktek, peserta terlihat antusias dan semangat membuat asseoris. Mereka bekerja secara sendiri dan bekerjasama. Bahkan sesama mereka bersaing dalam menghasilkan tas, kotak pensil dan bros sebagus dan sekreatif mungkin.

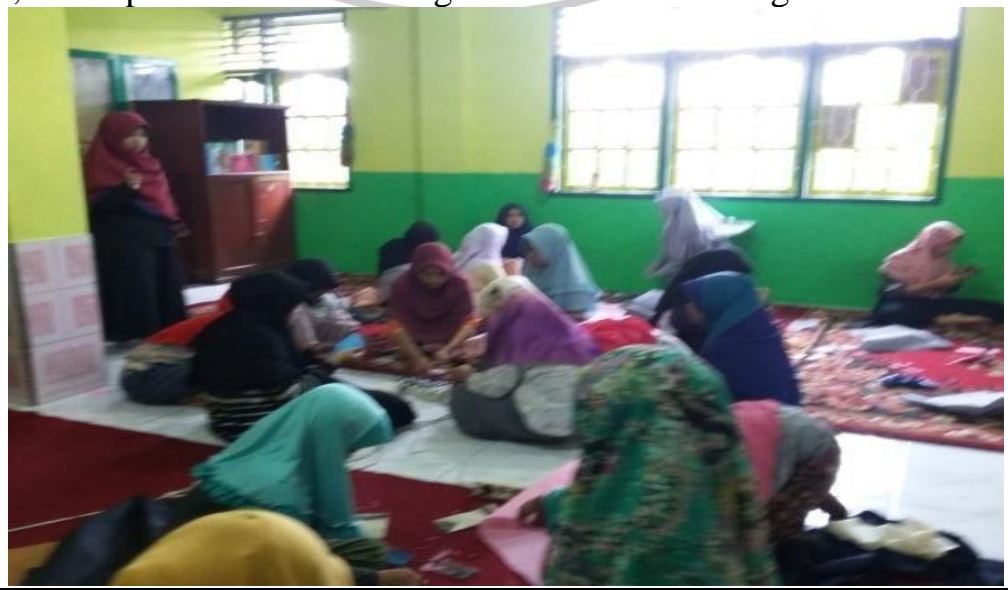




\section{Gambar 2. Instruktur sedang mendampingi praktek pembuatan assesoris}

Keempat, Advokasi wirausaha kreatif. Pada tahap ini dilakukan advokasi menjadi wirausaha kreatif yang mampu memanfaatkan potensi lingkungan sebagai sumber keuangan, cara menjual hasil produksi, baik ke pasar lokal maupun pemanfaatan media sosial. Strategi yang dilakukan adalah kepada teman sebaya, teman sekolah maupun ke tokodanorang-orang yang memiliki peluang untuk membeli assesoris tersebut. Pemasaran dilakukan secara langsung dan melalui media sosial. Dalam hal ini, karena anak asuh umumnya tidak memiliki handphone, maka mereka memanfaatkan handphone pengelola dengan menggunakan facebook danWA.

\section{Kesimpulan}

Pelatihan pembuatan assesoris dari sampah dapat merubah persepsi anak asuh terhadap sampah. Sebelumnya mereka menganggapbahwasampahbendakotor, tidak berguna dan harus dibuang, setelah kegiatan mereka memahami bahwa sampah bisa dimanfaatkan kembali dan bisa menghasilkan uang. Respon anak asuh dan pengelola panti sangat positif karena pelatihan pembuatan tas, bros dan kotak pensil dapat melatih keterampilan anak asuhnya, bahkan mereka memintakembali adanya kegiatan lain yang membuat mereka lebih kreatif dan produktif.

\section{Daftar Pustaka}

Korten, David C \& Syahrir. (1996). Pembangunan Berdimensi Kerakyatan. Jakarta: Yayasan Obor Indonesia.

Lauer, H. Robert. (1988). Perspektif Tentang Perubahan Sosial. Jakarta: Bina Aksara.

Martono, Nanang. (2011). Sosiologi Perubahan Sosial. Jakarta: Rajawali Pers.

Soekanto, Soerjono. (2007). Sosiologi Suatu Pengantar. Jakarta: Rajagrafindo Persada.

Suharto, Edy. (2005). Membangun Masyarakat Memberdayakan Rakyat. Bandung: Refika Aditama.

Syafrini, Delmira \& Nora Susilawati. (2012). Perubahan Kehidupan Masyarakat Melalui Bank Sampah (Studi Kasus: Bank Sampah Barokah Assalam Perumahan Dangau Teduh Kecamatan Lubuk Begalung Padang). Laporan Penelitian, UNP.

Syafrini, Delmira \& Nora Susilawati. (2015). Partisipasi Masyarakat Lokal dalam Mengembangkan Wisata Keluarga di Kawasan Wisata Pantai Purus Padang. Laporan Penelitian, UNP.

Syafrini, Delmira \& Nora Susilawati. (2017). Pembinaan Anak Panti Asuhan Menjadi Wirausaha Kreatif Dengan Pemanfaatan Sampah Rumah Tangga Menjadi Assesoris Unik dan Bernilai Jual di Panti Asuhan Asyiyah Ampang Kota Padang. Laporan Pengabdian Kepada Masyarakat, UNP. 